УДК 342.9

DOI: https://doi.org/10.54929/pmtl-issue1-2021-04

\title{
ОСНОВНІ НАПРЯМИ ПІДВИЩЕННЯ ЕФЕКТИВНОСТІ ТЛУМАЧЕННЯ АДМІНІСТРАТИВНО-ДЕЛІКТНИХ ПРАВОВИХ НОРМ
}

\author{
MAIN DIRECTIONS OF INCREASING THE EFFICIENCY \\ OF INTERPRETATION OF ADMINISTRATIVE-TORT LEGAL \\ STANDARDS
}

\author{
Лютіков П. С. \\ доктор юридичних наук, професор, \\ завідувач кафедри адміністративного та митного права, \\ Університет митної справи та фрінансів \\ ORCID: https:// 0000-0001-6173-0128 \\ Ліпинський В. В. \\ доктор юридичних наук, доцент, \\ директор ННI права та міжнародно-правових відносин, \\ Університет митної справи та фрінансів \\ ORCID: https:// 0000-0002-4373-3330
}

\author{
Pavlo Liutikov \\ University of Customs and Finance, Dnipro, Ukraine \\ Vladyslav Lipynskyi \\ University of Customs and Finance, Ukraine
}

Стаття присвячена визначенню концептуальних засад ефрективності тлумачення адміністративно-деліктнихправових норм. Викладено основні наукові положення, висновки та рекомендаціїза підсумками дослідження основоположних аспектів тлумачення положень законодавства, що визначає порядок провадження у справах про адміністративні правопорушення та їх адміністративно-деліктні наслідки на прикладі проваджень у справах про порушення податкового, митного та конкурентного законодавства. Обгрунтовано, що ці напрями удосконалення тлумачення адміністративно-деліктних норм права стосуються, насамперед, питань: 1) можливості притягнення до відповідальності за вчинення адміністративного правопорушення юридичних осіб; 2) повноваження судів у рамках адміністративно-деліктного судочинства; 3) запровадження додаткових процесуальних гарантій та вдосконалення правил тлумачення для більш повного дотримання основних засад адміністративно-деліктних проваджень та накладення адміністративних стягнень (рівність та змагальність, пропорційність, презумпція невинуватості, свобода від самовикриття, право мати достатній час та можливості для захисту, умотивованість рішень про застосування адміністративного стягнення). Ключові слова: адміністративно-деліктні правові норми, законодавство, ефрективність, правопорушення, тлумачення.

Статьяпосвященаопределениюконцептуальныхосновэффрективноститолкованияадминистративно-деликтных правовых норм. Изложены основные научные положения, выводы и рекомендации по итогам исследования основных аспектов толкования положений законодательства, определяющего порядок производства по делам об административных правонарушениях и их административно-деликтные последствия на примере производств по делам о нарушении налогового, таможенного и конкурентного законодательства. Обосновано, что эти направления совершенствования толкования административно-деликтных норм права касаются, прежде всего, вопросов: 1) возможности привлечения к ответственности за совершение административного правонарушения юридических лиц; 2) полномочия судов в рамках административно-деликтного судопроизводства; 3) введение дополнительных процессуальных гарантий и совершенствования правил толкования для более полного соблюдения основных принципов административно-деликтных производств и наложения административных взысканий (равенство и состязательность, пропорциональность, презумпция невиновности, свобода от саморазоблачения, право иметь достаточное время и возможности для защиты, мотивированность решений о применения административного взыскания). Ключевые слова: административно-деликтные правовые нормы, законодательство, эфрфективность, правонарушения, толкование.

The paper is aimed at defining the conceptual foundations of the effectiveness of the interpretation of administrative-tort legal norms; analysis of the main scientific provisions, conclusions and recommendations based on the results of the study of fundamental aspects of interpretation of the provisions of the legislation determining the procedure for 
proceedings on administrative offenses and their administrative-tort consequences on the example of proceedings on violations of tax, customs and competition law. The article presents the main scholarly provisions, conclusions, and recommendations based on the study of fundamental aspects of the interpretation of statutory regulations, which determine the procedure in administrative offense cases and their administrative delict consequences drawing on the examples of proceedings for violations of the tax and customs legislation as well as the competition law. It is being substantiated that these directions of improving the interpretation of administrative delict norms of law concern, first of all, the following issues: 1) the possibility of bringing legal entities to responsibility for the commission of an administrative offense; 2) court powers within the framework of administrative delict proceedings; 3) introduction of additional procedural guarantees and refinement of rules of interpretation for better compliance with the basic principles of administrative delict proceedings and imposition of administrative penalties (equality and adversarial nature of proceedings, proportionality, presumption of innocence, freedom from self-incrimination, the right to have adequate time and facilities for the preparation of the defense, justifiability of decisions on the imposition of an administrative penalty). The conclusion is substantiated that in order to increase the probability of revealing serious and difficult to investigate violations of the law, reducing the costs of administrative bodies to investigate them by encouraging offenders to plead guilty and facilitating the investigation of administrative tort law should be interpreted as allowing at least partial from liability under these conditions due to the existence of mitigating circumstances of an exceptional nature. Key words: administrative delict legal norms, legislation, efficiency, penalties, interpretation.

Постановка проблеми. Актуалізація питань визначення адміністративно-правового статусу людини і громадянина в контексті нинішніх умов розвитку держави та суспільства, необхідність перегляду ключових підходів до розуміння суті та призначення адміністративного права, обумовлених соціально-економічними трансформаціями у процесі державотворення, а також євроінтеграційними прагненнями України стали передумовою не тільки для оновлення сучасної доктрини адміністративного права та її методології, але й стали каталізатором дослідження низки як вузько спеціалізованих досліджень, так і фундаментальних, базисних блоків адміністративного права.

Важливим чинником успішності на цьому шляху є ефективна правотлумачна діяльність як суб'єктів офріційної інтерпретації, так і суб'єктів доктринального тлумачення норм адміністративно-деліктного права, що забезпечує надійну охорону прав і свобод громадян, власності, конституційного ладу України, встановленого правопорядку, зміцнення законності, запобігання правопорушенням, виховання громадян у дусі точного і неухильного додержання Конституції і законів України, поваги до прав, честі і гідності інших громадян тощо [1, с. 1-2].

Окрім вирішення безпосередніх завдань інституту адміністративної відповідальності, тлумачення норм адміністративно-деліктного права та ефрективність цього процесу справляють позитивний вплив на правозастосовчу практику у цій сорері, удосконалюють правотворчу діяльність, підвищують рівень правосвідомості та правової культури суб'єктів адміністративно-деліктних правовідносин і т. д. Враховуючи зазначене, вбачається, що наведені обставини обумовлюють необхідність та актуальність обраного вектору дослідження.

Визначаючи напрями вдосконалення теоретико-правового та законодавчого підґрунтя тлумачення правил провадження у справах про адміністративні правопорушення та накладення адміністративних стягнень, вважаємо за доцільне висловити міркування з питань: 1) можливості притягнення до відповідальності за вчинення адміністративного правопорушення юридичних осіб; 2) повноваження судів у рамках адміністративно-деліктного судочинства; 3) запровадження додаткових процесуальних гарантій та вдосконалення правил тлумачення для більш повного дотримання основних засад адміністративно-деліктних проваджень та накладення адміністративних стягнень (рівність та змагальність, пропорційність, презумпція невинуватості, свобода від самовикриття, право мати достатні час та можливості для захисту, умотивованість рішень про застосування адміністративного стягнення) [2, c. 361].

Аналіз останніх досліджень і публікацій. Слід зауважити, що в сучасній юридичній літературі відсутні комплексні праці, які присвячені засадам ефективності тлумачення норм адміністративно-деліктного права. У свою чергу, напрацювання представників теорії права і адміністративного права у цілому не враховують специфріку предмету, цілей і правових засобів адміністративно-деліктного правового регулювання, що додатково посилює потребу розвитку теорії ефрективності тлумачення адміністративно-деліктних норм права. Однак відповідні дослідження без сумніву справляють суттєвий вплив на науковий пошук більш вузької спеціалізації, якою є проблематика інтерпретації адміністративно-деліктного законодавства. Серед таких досліджень можна згадати праці таких вчених як О. В. Білоус, Ю. Л. Власов, М. М. Вопленко, Я. Н. Колоколов, О. П. Коренєв, М. М. Коркунов, О. І. Костенко, А. С. Піголкін, С. В. Прийма, П. М. Рабінович, Ю. Г. Ткаченко, О. Ф. Черданцев та ін $[3 ; 4 ; 5 ; 6 ; 7 ; 8]$.

Формулювання цілей статті (постановка завдання). Стаття присвячена визначенню концептуальних засад ефрективності тлумачення 
адміністративно-деліктних правових норм; аналізу основних наукових положень, висновків та рекомендацій за підсумками дослідження основоположних аспектів тлумачення положень законодавства, що визначає порядок провадження у справах про адміністративні правопорушення та їх адміністративно-деліктні наслідки на прикладі проваджень у справах про порушення податкового, митного та конкурентного законодавства..

Виклад основного матеріалу дослідження. Розпочинаючи визначення та наукове обґрунтування нововведень для вдосконалення законодавства про адміністративну відповідальність, насамперед, для його застосування до належного суб'єкта, який поліпшує свій фінансовий стан внаслідок вчинення адміністративного правопорушення особами із тісним правовим зв'язком із ним та ідентичними інтересами, а також піддається процесуальним примусовим заходам та наслідкам адміністративних стягнень, слід порушити питання про необхідність законодавчого визнання юридичних осіб суб'єктами адміністративних правопорушень для визначення предмета тлумачення адміністративно-деліктних правових норм так, щоб він охоплював обставини діяльності таких юридичних осіб, пов'язаних із адміністративним правопорушенням, та щоб з їх урахуванням визначалась справедлива правова процедура та пропорційні адміністративні стягнення.

У цьому зв'язку, перш за все, нагадаємо, що за змістом роз'яснень міжнародних організацій, що спеціалізуються на питаннях митного адміністрування, країни загального права та деякі окремі країни цивільного права давно запровадили концепцію про відповідальність юридичних осіб, зважаючи на те, що учасниками експортно-імпортних операцій зазвичай $є$ юридичні особи, а їх розмір та структура не завжди дозволяє встановити фрізичну особу, яка $є$ вигодонабувачем від правопорушення або бути єдиним суб'єктом, відповідальним за рішення, дію чи бездіяльність, яка визнана порушенням митних правил (наприклад, у випадку невиконання митних правил через недбалість правопорушення зазвичай $є$ не стільки результатом одноособового рішення, скільки декількох корпоративних структур). Більше того, за слушним зауваженням А. В. Дусик, незважаючи на те, що у контексті провадження у справах про порушення митних правил юридичні особи офіційно не визнаються суб'єктами адміністративної відповідальності, саме вони несуть негативні наслідки в результаті застосування митної конфіскації та піддаються деяким специфічним процесуальним діям (наприклад, митне обстеження чи взяття проб і зразків для проведення експертизи), які орієнтовані саме на юридичних осіб. Однак, за юридичними особами не закріплюється можливість реалізації жодних правових гарантій чи захисних юридичних інструментів власних прав та законних інтересів, адже їх участь у відповідних адміністративно-деліктних провадженнях $€$ неможливою [9, с. 35]. Як вже було з'ясовано за підсумками опрацювання практики ЄСПЛ, це є несумісним із вимогою ст. 7 Конвенції виключити можливість покарання особи за злочин, вчинений іншою особою, що рівною мірою стосується як фрізичних, так й юридичних осіб. Призначення юридичним особам кримінального покарання (яким за у розумінні цього міжнародно-правового документа $є$ значна кількість адміністративних стягнень) за обставин, коли вони не були учасниками будь-якого кримінального провадження, адже обвинувачення пред'явили лише їх законним представникам у особистій якості, а питання про недобросовісний та кримінально-караний характер рішень юридичних осіб у рамках кримінальних проваджень відносно ії̈ законних представників та учасників, не поставало, не відповідає зазначеній вимозі, що викликає необхідність внесення відповідних змін та доповнень у законодавство України про адміністративну відповідальність для визнання юридичних осіб суб'єктами адміністративних правопорушень та розширення можливостей щодо тлумачення адміністративно-деліктних правових норм у відповідних справах [2, с. 263-364].

Наступним кроком до вдосконалення практики тлумачення норм законодавства про адміністративну відповідальність $€$ виключення безпідставного самоусунення судів у ході адміністративно-деліктного судочинства від перевірки правильності встановлення компетентним адміністративним органом обставин справи та їх оцінки, справедливості адміністративного стягнення та усіх інших аспектів адміністративного рішення $з$ посиланням на дискреційність повноважень відповідних адміністративних органів, їх виключність або зв'язок з вивченням складних вузькоспеціалізованих питань, для чого ніби лише у працівників відповідних адміністративних органів $є$ достатня експертиза.

Так, за підсумками дослідження практики ЄСПЛ було з'ясовано, що для відповідності конвенційним стандартам справедливого судового розгляду національне законодавство має забезпечувати право на судове оскарження рішення адміністративного органу про накладення адміністративних стягнень, які у розумінні Конвенції $\epsilon$ рівнозначними кримінальним покаранням, із закріпленням за судами юрисдикції над обставинами справи та їх юридичною оцінкою. Виявляючи повагу до прерогативи адміністративних органів щодо управління публічними справами, незалежності та завдання судів, ця міжнародна 
судова установа вказала на те, що національний суд має опрацьовувати усі питання фактів та права для встановлення законності та обґрунтованості рішення адміністративного органу, незалежно від технічного, економічного чи будь-якого іншого складного характеру питання, його зв'язку з безпекою суспільства тощо, що може бути спонукати лише до залучення експертів та/або передання справи на розгляд колегії спеціалізованих суддів, але не до відмови судів від юрисдикції над справою. Так само, від судів очікується перевірка пропорційності адміністративного стягнення із можливістю зміни його розміру для приведення його у відповідальність із вимогами верховенства права. Примітним також $є$ те, що наведена позиція узгоджується з практикою Європейського суду справедливості, згідно з якою суди не можуть посилатись на свободу розсуду Європейської Комісії як на підставу для відмови від проведення ґрунтовного перегляду питань права та фрактів, навіть якщо йдеться про тлумачення комісією інформації економічного характеру [2, с. 364].

Виконання вищевикладених вимог $є$ необхідним не лише для забезпечення справедливого судового розгляду, а й для дотримання процесуальних гарантій мирного володіння майном відповідно до ст. 1 Першого протоколу до Конвенції, за яким будь-яке втручання у мирне користування майном (у тому числі накладення штрафу або застосування оплатного вилучення чи конфіскації як адміністративних стягнень) має супроводжуватись процедурними гарантіями, що надають заінтересованій особі, зокрема, право на ефективне оскарження заходів втручання, під час якого має бути встановлений справедливий баланс між конфліктуючими приватним та публічним інтересами. Водночас, неприпустимим зважаючи на поділ влади та виключність компетенції суб'єктів владних повноважень є вихід у рамках судового контролю за законністю та обґрунтованістю їх рішень про накладення адміністративного стягнення за межі правосуддя, що може виражатись, наприклад, у визначенні іншого заходу державного реагування у спірних правовідносинах, або ухвалення замість суб'єкта владних повноважень рішення до того, як він мав можливість прийняти владне управлінське рішення у межах повноважень та строків, передбачених законом.

Зважаючи на вищевикладене, неприйнятним $€$ тлумачення адміністративно-деліктних правових норм про повноваження судів у рамках судового оскарження рішень адміністративних органів про накладення адміністративного стягнення так, ніби вони не допускають повторного встановлення обставин справи або їх переоцінки судом, так само як й перевірки на пропорцій- ність обраного адміністративним органом адміністративного стягнення, зважаючи на наділення адміністративного органу у відповідних правовідносинах дискреційними повноваженнями або на складний характер відповідного питання, що має значення для вирішення. Натомість, під час адміністративно-деліктного судочинства суд має перевіряти правильність встановлення компетентним адміністративним органом обставин справи та їх оцінки, справедливість накладеного адміністративного стягнення та усі інші аспекти адміністративного рішення, незважаючи на дискреційність повноважень адміністративного органу з того чи іншого питання, технічного, економічного чи будь-якого іншого складного характеру того чи іншого питання, його зв'язку з безпекою суспільства тощо, користуючись за необхідності допомогою експертів чи спеціалістів [2, с. 364-365].

Переходячи до висловлення наукових рекомендацій щодо належного тлумачення загальних засад адміністративно-деліктного законодавства з урахуванням міжнародних стандартів та найкращих зарубіжних практик, розпочнемо з обґрунтування позиції про необхідність забезпечення відповідності адміністративно-правових санкцій за порушення конкурентного законодавства його загальним цілям.

Зокрема, під час наукового опрацювання питань тлумачення конкурентного законодавства було підкреслено, що, визнаючи положення конкурентного законодавства та базового адміністративно-деліктного закону про санкції за порушення конкурентного законодавства нерозривно пов'язаними з його цілями, очевидним $є$ те, що кожна санкція має спрямовуватись на підтримку та захист економічної конкуренції, обмеження монополізму в господарській діяльності для забезпечення ефективного функціонування економіки України на основі розвитку конкурентних відносин, що виключає врахування під час вирішення питання про винуватість суб'єкта господарювання у антиконкурентних діях обставин, які не охоплюються метою конкурентного законодавства, таких як, наприклад, захисту національного товаровиробника та інтересів споживачів поза зв'язком із справедливістю конкуренції.

Продовжуючи висловлення рекомендацій щодо належного тлумачення загальних засад адміністративно-деліктного законодавства вважаємо за доцільне визначити те, як має тлумачитись у контексті провадження у справах про адміністративні правопорушення та вирішення питання про застосування адміністративного стягнення всеосяжний та визначальний принцип пропорційності.

Нагадаємо, що пропорційність як основоположна вимога державного втручання у реалізацію 
прав, свобод та законних інтересів встановлює необхідність дотримання справедливого балансу між несприятливими наслідками державного втручання у реалізацію прав, свобод та законних інтересів та цілями, на досягнення спрямоване це втручання [2, с. 366]. Справедливий баланс не вважається забезпеченим, якщо на особу внаслідок втручання покладається надмірний тягар, тобто більш деструктивний, ніж той, що був би достатнім з урахуванням усіх обставин справи, у тому числі особливостей становища особи. У контексті тлумачення адміністративно-деліктних правових норм, якими передбачається можливість накладення адміністративних стягнень та обмеження прав особи іншим чином, пропорційність вимагає під час застосування цих обмежувальних заходів визначення того, чи можна було б досягти належного карального, стримувального чи іншого ефекту за допомогою менш інтенсивних адміністративних стягнень чи інших заходів втручання (що викликає необхідність для компетентного державного органу розглянути можливість ухвалення менш суворих обмежувальних рішень) для досягнення справедливого балансу між відповідним суспільним інтересом та правами особи, яка притягається до відповідальності за адміністративне правопорушення, уникаючи застосування заходів втручання, що $€$ автоматичним, безвідносним до індивідуальних обставин справи особи та негнучким.

У цьому зв'язку зазначимо, що за підсумками дослідження адміністративно-деліктного законодавства України виявлена його явна невідповідність вимозі про пропорційність адміністративних стягнень, насамперед у тій частині, що регулює застосування адміністративних стягнень за порушення митних правил. Зокрема, йдеться про те, що санкціями положень митного законодавства, які визначають склади порушень митних правил, штрафи встановлюються у твердій сумі (без нижніх та верхніх меж допустимих сум штрафів), а конфіскація $є$ безумовним та безальтернативним стягненням, якщо вона передбачається за вчинення того чи іншого порушення митних правил. Очевидним $є$ те, що накладення адміністративних стягнень 3 незмінними значеннями без можливості належного врахування під час визначення їх виду та розміру обставин справи $€$ несумісним із принципом пропорційності, який, між іншим, послідовно проголошується у міжнародних стандартах митного адміністрування, відображених у Митному кодексі ЄС, Конвенції про спрощення та гармонізацію митних процедур, Угоді про спрощення процедур торгівлі (Протокол про внесення змін до Марракеської угоди про заснування Світової організації торгівлі), а також закріплюється у положеннях митного законодавства найбільш розвинених країн [2, с.
367].

При цьому, не викликає сумнівів те, що для тлумачення цих адміністративно-деліктних правових норм з дотриманням пропорційності зміна їх буквального змісту не $є$ нагальною необхідністю, адже пропорційність як складова верховенства права $є$ принципом із більшою юридичною силою, ніж ці адміністративно-деліктні правові норми, що дозволяє відступити від них та належним чином забезпечити відповідність адміністративних стягнень за порушення митних правил тяжкості та наслідкам цих порушень, ступеню вини правопорушника з урахуванням усіх обставин справи, що пом'якшують та обтяжують його відповідальність, та вимагає обмежуватись застосуванням якомога більш м'яким видом та розміром адміністративних стягнень, достатнім для досягнення цілей адміністративних стягнень за порушення митних правил. Зарубіжний досвід найбільш розвинених країн показав, що обставинами, що пом'якшують адміністративну відповідальність за порушення митних правил, слід визнавати вчинення правопорушення вперше 3 необережною формою вини або без значних наслідків для державного бюджету через недоотримання доходів; вжиття усіх можливих кроків для уникнення правопорушення, зокрема звернення до митних органів з проханням про консультацію чи іншу допомогу; добросовісна помилка у складних питань митного адміністрування через недосвідченість; зв'язок правопорушення із комплементарною помилкою митних органів, співпраця під час розслідування митних органів; позитивна історія взаємодії із митними органами тощо.

Цей самий недолік, який також може бути виправлений тлумаченням відповідних положень митного законодавства, що узгоджується із принципом пропорційності, відображає правова основа конфіскації за порушення митних правил. Тоді як сума штрафу може бути адаптована до тяжкості порушення та ступеню вини правопорушника з урахуванням усіх обставин справи, що мають значення, конфіскація може бути приведена у відповідність до обставин відповідного порушення митних правил та особливостей ситуації правопорушника, насамперед, шляхом відмови від її застосування за умови встановлення виключних пом'якшуючих обставин, з-поміж яких, зокрема можливість повернути спеціально перероблений чи пристосований для вчинення порушень митних правил транспортний засіб до попереднього стану для використання за основним призначенням.

На противагу вищенаведеним випадкам, у яких безальтернативне адміністративне стягнення за деяких обставин справи може виявитись надмірно суворим, адміністративно-деліктне 
законодавство України містить положення, які не узгоджуються із принципом пропорційності через те, що найбільш суворе адміністративне стягнення за адміністративне правопорушення $€$ недостатнім для досягнення карального, стримувального та виховного ефекту для правопорушника. Зокрема, під час тлумачення адміністративно-деліктних положень конкурентного законодавства слід виходити з того, що адміністративні штрафри за антиконкурентні правопорушення за КУпАП є настільки незначними, що вони у найбільшому значенні зі встановленого законом діапазону відповідають за ступенем суворості найменш тяжкому антиконкурентому правопорушенню за будь-яких обставин, що дозволяє безумовно застосовувати до правопорушників штраф у найбільшому розмірі. Це забезпечить реалізацію пропорційності у її частині, згідно з якою вид та розмір санкцій має бути співмірним з масштабом та характером порушення, забезпечуючи належне покарання за вчинене правопорушення та стримування від вчинення чи продовження таких порушень [10, с. 330-331].

Продовжуючи визначення найбільш загальних шляхів вдосконалення тлумачення адміністративно-деліктних правових норм, зазначимо, що цей процес, незалежно від місця та призначення таких правових норм, що складають предмет тлумачення, неодмінно має включати встановлення їх відповідності закріпленим міжнародними стандартами захисту прав людини та належного урядування, критеріям якості норм права, які охоплюють їх доступність та передбачуваність їх застосування.

Насамперед, верховенство права у частині його вимог про якість законодавства визнає допустимим застосовування лише того законодавства, формулювання положень якого $є$ достатньо конкретними та зрозумілими з урахуванням особливостей суспільних відносин, передусім, їх учасників, до яких звернений відповідний закон, щоб вони мали розумну можливість управляти своєю поведінку із усвідомленням усіх її можливих наслідків (формальностей, умов, обмежень або санкцій) відповідно до цих положень законодавства. Цими особливостями суспільних відносин, які визначають належний ступінь передбачуваності законодавства, є, зокрема, участь у них представників тих професій, які мають здійснювати діяльністю з великою обережністю та виявляти особливу увагу до оцінки ризиків, якими супроводжується їх діяльність; участь у них підприємств, від яких розумно очікувати звернення за професійною юридичною порадою для з'ясування змісту вимог законодавства.

Разом з тим, вимога про передбачуваність застосування адміністративно-деліктного зако- нодавства не має абсолютизуватись, адже, наприклад, у контексті санкцій за антиконкурентні дії однаково необхідним для забезпечення належного виконання ними їх карального та превентивного призначення не можна допускати можливість суб'єктів господарювання заздалегідь розрахувати розмір штрафу за правопорушення та за підсумками зіставлення потенційних доходів від антиконкурентного правопорушення із сумою штрафу за нього із достатньо впевненістю визначати економічну доцільність антиконкурентних дій [10, с. 331-332].

На доповнення до передбачуваності самого позитивного законодавства, верховенство права містить очікування щодо судового тлумачення норм права, адже загальновизнаним є те, що навіть у належним чином опрацьованих правових положеннях, в будь-якій частині національного законодавства присутній неминучий елемент судового тлумачення для роз'яснення абстрактних норм права і для адаптації до обставин, що змінюються. Зокрема, у контексті адміністративних правопорушень із кримінально-правовою природою, вимагається, щоб судове тлумачення відповідало формулюванню положення кримінального закону, що сприймається в контексті фактичних обставин справи, було обґрунтованим, дотримувалось усталених тенденцій у розвитку практики національних судів або містило послання на виключні обставини, що виправдовують відступ від цих тенденцій.

Осмисливши вищевикладене, безсумнівним видається те, що під час адміністративно-деліктного судочинства має перевірятись можливість застосування відповідних норм з огляду на дотримання ними належного ступеня передбачуваності та, для належного правозастосування, має конкретизуватись їх зміст, якщо з тих чи інших причин він не $є$ повністю зрозумілим. На виконання цього завдання та з урахуванням раніше отриманих наукових результатів, можемо рекомендувати, насамперед, заповнити прогалину митного законодавства у питанні кінцевого строку накладення адміністративного стягнення, який відраховується від дня вчинення правопорушення шляхом застосування за аналогією закону мінімального кримінально-правового строку давності, що становить два роки з дня вчинення нею кримінального правопорушення за кримінальним законом, якщо не матимуть місця виключні обставини.

Обґрунтувавши необхідність та оптимальні шляхи зміни та доповнення адміністративно-деліктного законодавства для коригування його тлумачення правильним визначенням суб'єкта вчинення адміністративного правопорушення, висловившись щодо належного тлумачення законодавчих положень про юрисдикцію суду над 
обставинами справи та їх правовою оцінкою, а також дійшовши висновків щодо того, як принцип пропорційності та вимога про передбачуваність застосування норм права мають впливати на тлумачення адміністративно-деліктного законодавства, перейдемо до визначення рекомендацій щодо тлумачення процесуальних та деяких спеціальних принципів у рамках провадження у справі про адміністративне правопорушення.

Ознайомившись із практикою тлумачення та застосування ЄСПЛ принципів рівності сторін та змагальності судового процесу як процесуальних гарантій справедливого судового розгляду, а також із деякими міркуваннями вчених щодо реалізації цих принципів у адміністративно-деліктних провадженнях за законодавством України, маємо можливість констатувати, що вони мають тлумачитись так, що вони зобов'язують адміністративний орган або суд як інстанцію, яка приймає первинне рішення про адміністративну відповідальність особи або переглядає це рішення у порядку судового оскарження, зокрема, забезпечити особі, яка притягається до відповідальності, можливість допитати будь-якого свідча або подати будь-який доказ на обґрунтування її позиції, а також одержати докази шляхом їх витребування, крім випадків, коли вони не мають значення для вирішення справи або заява про їх витребування не супроводжується належним обґрунтуванням.

Також, у світлі цих принципів суд у рамках судового провадження у справі про адміністративне правопорушення не має за власною ініціативою збирати викривальні докази. Більше того, за твердженням О. М. Курила та С. О. Билі сама відсутність сторони обвинувачення накладає на суд не притаманних йому функцій обвинувача у справі про адміністративне правопорушення, насамперед, у випадках, коли особа заперечує обставини, що зазначені в протоколі про адміністративне правопорушення [11, с. 46]. Зважаючи на це, вкрай необхідним є підтримання позиції про винуватість особи у вчиненні адміністративного правопорушення прокурором або іншою уповноваженою посадовою особою, насамперед, у тих справах, у яких застосовними є кримінальний аспект стандартів справедливого судового розгляду через кримінальну природу адміністративного стягнення, яке загрожує правопорушнику.

Належний обсяг процесуальних можливостей для особи, яка притягається до відповідальності за адміністративне правопорушення, та змагальність адміністративно-деліктного провадження можуть також забезпечуватись шляхом тлумачення процесуальних адміністративно-деліктних правових норм таким чином, щоб обов'язковим визнавалось надання цій особі достатнього часу та можливостей для подання пояснень 3 метою їх врахування для ухвалення законного та обґрунтованого остаточного рішення у справі про адміністративні правопорушення [2, с. 371-372].

Висновки. Підбивши підсумки щодо шляхів належного тлумачення адміністративно-деліктних правових норм для дотримання процесуальних гарантій, відображених у міжнародних стандартах правосуддя, наведемо певні міркування щодо спеціальних вимог, необхідність виконання яких у рамках більшості адміністративно-деліктних проваджень продиктована кримінально-правовим характером адміністративних правопорушень та стягнень. Як показав аналіз практики ЄСПЛ у частині застосування кримінального аспекту ст. 6 Конвенції, цими спеціальними вимогами $є$, насамперед, дотримання презумпції невинуватості та забезпечення права мати достатній час та можливості для захисту. Оскільки право на достатній час та можливості для захисту вже зачіпалось раніше у контексті рівності та змагальності процесу, кристалізуючи правила тлумачення адміністративно-деліктних правових норм, які $є$ сумісними із презумпцією невинуватості, зазначимо, що цими правилами $\epsilon$, насамперед: покладення тягаря доказування на сторону обвинувачення; тлумачення будьяких сумнівів на користь обвинуваченого, що, зокрема, тягне за собою визнання неправосудним недостатньо мотивоване рішення про винуватість особи без належного обґрунтування цього висновку та без спростування усіх обґрунтованих сумнівів; тлумачення будь-яких сумнівів на користь обвинуваченого, що, зокрема, тягне за собою визнання неправосудним недостатньо мотивоване рішення про винуватість особи без належного обґрунтування цього висновку та без спростування усіх обґрунтованих сумнівів.

Водночас, має враховуватись загальновизнана позиція щодо того, що репресивність адміністративних проваджень стягнень є дещо меншою, ніж та яка властива власне кримінальним провадженням та покаранням, що обумовлює послаблення вимог стандарту доказування та презумпції невинуватості у адміністративно-деліктних провадженнях. Зокрема, під час дослідження встановлених європейським законодавством правил правозастосування у справах про порушення законодавства про захист економічної конкуренції було встановлено, що незважаючи на подібність адміністративних стягнень за антиконкурентні правопорушення до кримінальних покарань, стандарти доказування у цих справах не мають повною мірою за ступенем суворості відповідати кримінально-процесуальним вимогам, що, серед іншого, не виключає об'єктивну відповідальність суб'єктів господарювання за антиконкурентні правопорушення, 
якщо дотримана загальна справедливість провадження. Так само, відповідно до практики ЄСПЛ визнається цілком допустимим за умови дотримання справедливого балансу між правом на захист та інтересами правосуддя встановлення презумпцій винуватості у цих провадженнях, таких як презумпція відповідальності водія за залишення місця дорожньо-транспортної пригоди або невиконання обов'язку зупинитись та повідомити поліцію про дорожньо-транспортну пригоду; роботодавця за незаконне працевлаштування іноземця; власника транспортного засобу за вчинення дорожньо-транспортного правопорушення; платника податків за податковий борг; володільця контрабандних товарів тощо.

У контексті вдосконалення правового регулювання та під час правозастосування законодавчих положень, що стосуються тимчасового вилучення речей і документів у рамках адміністративно-деліктних проваджень необхідно вказати на такі ключові ідеї.

Перш за все, належна увага має бути приділена визначальним аспектам тимчасового вилучення речей і документів. Як показав аналіз адміністративно-деліктного законодавства, у його положеннях немає достатнього ступеню деталізації гарантій забезпечення захисту прав та законних інтересів власників від вилучення їх речей та документів, яке у світлі обставин справи є нерозумним та непропорційним. Позитивним кроком видається тлумачення принци- пів права та правових принципів, спрямованих на захист права власності так, що вони дозволяють достроково повертати вилучені речі та документи за виключних обставин, зокрема, за зразком, встановленим законодавства США, якщо немає щодо конкретних речей та документів активного кримінального провадження або іншого паралельного адміністративно-деліктного провадження та має місце будь-яка з цих обставин: 1) за матеріалами справи очевидно, що конфіскація не підлягає застосуванню до тимчасово вилучених товарів та транспортних засобів комерційного призначення; 2) заявник вносить грошову заставу, яка дорівнює вартості тимчасово вилучених товарів та транспортних засобів комерційного призначення; 3) заявник врегулював із митними органами усі питання, зокрема, сплатив усі митні платежі та компенсував витрати митних органів на провадження у відповідній справі.

Крім того, для підвищення ймовірності розкриття тяжких за наслідками та складних для розслідування порушень законодавства, зменшення витрат адміністративних органів на їх розслідування шляхом заохочення правопорушників до визнання винуватості та сприяння розслідуванню положення актів адміністративно-деліктного законодавства слід тлумачити так, що вони допускають принаймні часткове звільнення від відповідальності за цих умов через наявність пом'якшуючих обставин виняткового характеру.

\section{БІБЛІОГРАФІЧНИЙ СПИСОК:}

1. Ліпинський В.В. Ефективність тлумачення адміністративно-деліктних правових норм: автореф. дис. доктора юрид. наук. Дніпро, 2021. 38 с.

2. Ліпинський В.В. Ефективність тлумачення адміністративно-деліктних правових норм: дис. ... доктора юрид. наук: 12.00.07. Дніпро, 2021. 439 с.

3. Liutikov P., Bilous O. The concepts and the essence of interpretation of law. Baltic Journal of Economic Studies. 2021. Vol 7, No 1. p. 139-144.

4. Колоколов Я. Н. Аутентическое официальное толкование норм права: теория, практика, техника : автореф. дисс. ... канд. юрид. наук. Нижний Новгород, 2011. 36 с.

5. Костенко О. І. Тлумачення актів адміністративного законодавства : автореф. дис. ... канд. юрид. наук. Запоріжжя, 2011. 18 с. $26 \mathrm{c}$.

6. Ткаченко Ю. Г. Толкование юридических норм в СССР : автореф. дис. ... докт. юрид. наук. Москва, 1950.

7. Коренев А.П. Нормы административного права и их применение. М., 1978. 142 с.

8. Черданцев А. Ф. Толкование права и договора : учебное пособие. Москва, 2003. 381 с.

9. Дусик А. В. Провадження у справах про порушення митних правил :. дис. ... канд. юрид. наук (уривок) : 12.00.07. Харків, 2006. 185 с.

10. Ліпинський В.В. Тлумачення адміністративно-деліктних правових норм: теоретико-правові та праксеологічні аспекти: монографія. Одеса: Видавничий дім «Гельветика», 2020. 390 с.

11. Курило О. М., Биля С. О. Недоліки правового регулювання судового розгляду справ про адміністративні правопорушення. Вісник Верховного Суду України. 2010. № 8 (120). С. 43-48.

\section{REFERENCES}

1. Lipynskyi, V. V. (2021). Efektyvnist' tlumachennja administratyvno-deliktnyh pravovyh norm [Efficiency of Interpretation of Administrative-Tort Legal Rules]. Thesis. Dnipro. (in Ukrainian).

2. Lipynskyi, V. V. (2021). Tlumachennja administratyvno-deliktnyh pravovyh norm: teoretyko-pravovi ta prakseologichni aspekty [Interpretation of administrative-tort legal norms: theoretical-legal and praxeological aspects]. Treatise. Odesa: Publishing House Helvetica. (in Ukrainian). 
3. Lipynskyi, V. V. (2021). Efektyvnist' tlumachennja administratyvno-deliktnyh pravovyh norm [Efficiency of Interpretation of Administrative-Tort Legal Rules]. Dissertation. Dnipro. (in Ukrainian).

4. Liutikov, P., Bilous, O. (2021). The concepts and the essence of interpretation of law. Baltic Journal of Economic Studies. Vol 7, No 1. p. 139-144.

5. Kolokolov, Ya. N. (2011). Autenticheskoe oficial'noe tolkovanie norm prava: teorija, praktika, tehnika [Authentic official interpretation of the rule of law: theory, practice, technique]. Thesis. Nizhniy Novgorod. (in Russian).

6. Kostenko, O. I. (2011). Tlumachennja aktiv administratyvnogo zakonodavstva: [Interpretation of acts of administrative legislation]. Thesis. Zaporizhzhia. (in Ukrainian).

7. Tkachenko, Ju. G. (1950) Tolkovanie juridicheskih norm v SSSR [Interpretation of legal norms in the USSR]. Thesis. Moscow. (in Russian).

8. Korenev, A.P. (1978) Normy administrativnogo prava i ih primenenie. [Administrative law and their application]. Moscow, 1978. (in Russian).

9. Cherdancev, A. F. (2003) Tolkovanie prava i dogovora [Interpretation of law and contract]. Moscow. (in Russian).

10. Dusyk, A. V. (2006). Provadzhennja u spravah pro porushennja mytnyh pravyl [Proceedings in cases of violation of customs rules]. Dissertation. Kharkiv. (in Ukrainian).

11. Kurylo, O.M., Bylya, S.O. (2010). Nedoliky pravovogo reguljuvannja sudovogo rozgljadu sprav pro administratyvni pravoporushennja. [Disadvantages of legal regulation of court proceedings in cases of administrative offenses]. Visnyk Verhovnogo Sudu Ukrai'ny. [Bulletin of the Supreme Court of Ukraine]. № 8 (120). p. 43-48. (in Ukrainian).

11. Kurylo O.M., Bylya S.O. (2010). Nedoliky pravovogo reguljuvannja sudovogo rozgljadu sprav pro administratyvni pravoporushennja. [Disadvantages of legal regulation of court proceedings in cases of administrative offenses]. Visnyk Verhovnogo Sudu Ukrai'ny. [Bulletin of the Supreme Court of Ukraine]. № 8 (120). p. 43-48. (in Ukrainian) 